\title{
The Banking Sector of Pakistan: The Case of Its Growth and Impact on Revenue Generation 2007 to 2012
}

\author{
Sana Zafar, Dr. Farooq Aziz \\ Research Scholar of Department of Education and Social Sciences, Hamdard University, Pakistan \\ Faculty of Department of Education and Social Science, Hamdard University, Pakistan
}

\begin{abstract}
The banking sector of Pakistan played an important role in the growth and development of the economy of Pakistan. This study aims to find the reasons behind the growth of the banking sector and how it can influence the revenue generation of the sector. The reasons are investigated and the current state of the banking sector is also reviewed to study the growth patterns. The historical evidence is first collected and then analyzed, so the current survival of the sector could be studied even after the Global Financial Crisis. Financial Soundness Indicators provide further indept analyses of the factors which contributed towards the growth of the banking sector of Pakistan. The reforms in the banking sector which are the real reasons for the growth in the banking sector are summarized under the rationale behind growth in the banking sector of Pakistan. The banking sector of Pakistan is the only sector of the economy which survived the Global Financial Crisis. So, this study provides evidence that Pakistan's banking sector is still resilient and is profitable which suggests that it's still a healthy sector for the investors to make safe investments with reliable and consistent returns. The government and the common man both can be benefited by the positive performance of the banking sector of Pakistan.
\end{abstract}

Keywords: banking sector growth, economic growth, revenue generation, survival through global financial crisis, financial soundness indicators

\section{INTRODUCTION}

The purpose of this study is to find out the main reasons of growth in the banking sector of Pakistan and how it contributes to revenue generation. As the banking sector plays an important role in the economic development of the country so the government of Pakistan must support this sector. The growth in the banking sector was observed after 1990 when liberalization was done through banking sector reforms .Bank is a financial institution which lends money and safeguards the deposits of the bank account holders. These deposits can be withdrawn by cheques. Banks are considered as financial intermediaries. The function of a financial intermediary is to sell the products designed by them to make money. The banks acquire interest by selling their obligations. The Pakistani banking sector has gone through different phases of growth. The sector was directed by the government of Pakistan to implement the development strategies till 1980's (Hardy \& Patti, 2001, p.13). To stabilize the financial and banking sector of Pakistan, the government nationalized the institutions so the declining economic growth can be revived (Akhtaret al., 2010). Later in 1990, the government of Pakistan liberalized and deregulated the banking sector. To maintain the market based banking, the government privatized the government banks and also made relaxations to help the private sector to open up new private banks. The target was to improve the management system and increase the earning of banks by strengthening the quality of assets provided by the banks. Other then this, relaxations were provided in credit control, deregulations were observed in interest rates and capital market developments helped in creation of competitive environment in the banking industry of Pakistan (Akhtaret al., 2010).

The banking sector of Pakistan has gone through three phases which are pre-nationalization, nationalization and post nationalization. In pre-nationalization phase, Australian Bank Ltd. and Habib Bank Ltd. were the only two banks after the partition of Pakistan and India on August 14, 1947. For both the newly established countries, the Reserve Bank of India was performing as the central bank. A need was felt to establish the banking sector of Pakistan because the Reserve Bank of India was not performing its functions fairly for Pakistani banking industry. The Pakistani government founded State Bank of Pakistan in 1948 and National Bank of Pakistan in 1949. The Government then launched State Bank of Pakistan act in 1956 and introduced Banking Companies Ordinance in 1962 for the development of banking sector of Pakistan. The second phase began in 1974. The government decided to nationalize the banking sector by merging all the banks and established five banks. The last phase which is titled post nationalization began in 1990 when the government of Pakistan privatized the banks and denationalized two financial institutions by making amendments in National Act of 1974. The government made relaxation in the policy of opening up of private banks which encouraged the private sector to grow. 
The Pakistani banking industry encompasses nationalized commercial banks, private banks, public sector banks, foreign banks, Islamic banks, specialized banks and microfinance banks. There are some companies in Pakistan which are working as banks so the financial sector can develop along with economic growth. In 1993, 33 commercial banks were functioning out of which 19 were foreign and 14 were local banks. By the end of 2001, the number of commercial banks increased to 43, out of which 19 were foreign banks and 24 were local banks ( Akhtaret al.,2010). In 2010, the number of bank branches reached 9,348 which comprised of 25 domestic private banks, five public commercial banks, four specialized banks and six foreign banks(Khalabat, 2011, para 8). At present, the State Bank of Pakistan is regulating 46 banks which comprise of 39 local banks and seven foreign banks. The local banks comprise of four specialized banks, five public sector banks, five Islamic banks, eight microfinance banks and 17 private banks (State Bank of Pakistan, 2012). This indicates that the banking sector of Pakistan is growing rapidly. This research paper will contribute towards the body of knowledge of the banking sector of Pakistan. It will provide guidelines for the banking sector and it will be helpful for the government of Pakistan to formulate economic policies. Moreover, this research will help other researchers in the field. This research paper not only examines the reasons of growth in the banking sector of Pakistan but also examines the financial soundness indicators which are the real reasons of growth in the banking sector.

\section{RESEARCH OBJECTIVES}

The main objective of this study is to investigate the factors which contributed towards growth in the banking sector of Pakistan and how it influenced the revenue generation of the banks. The specific objectives of this research are as follows.

i. Historical evidences are provided to study the developments in the banking sector of Pakistan.

ii. Current overview of the banking sector is provided.

iii. Main reasons are investigated to study the rapid growth in the banking sector of Pakistan.

iv. To measure the impact of revenue generation by banks in Pakistan.

\section{LITERATURE REVIEW}

Before the partition of Pakistan and India in 1947, the banking in Pakistan was dominated by the British banks (Ghazanfar, 2011). Only two banks were located in Pakistan's territory at the time of independence with total deposited amount of 880.0 million (Qayyum, 2007). Some banks of Pakistan faced liquidation and the payments were not made to the depositors (Ghazanfar, 2011). Steps were taken to handle such issues and to establish the banking industry of Pakistan. In 1948, State Bank of Pakistan was established (Qayyum, 2007). The operating domestic bank branches were only 25 out of 195(Ghazanfar, 2011). The State Bank of Pakistan focused on promoting the banking industry so trade and commerce can be promoted in the country (Shirazi, 2010). The State Bank of Pakistan supported Habib Bank Limited, National Bank of Pakistan and Allied Bank Limited to achieve this objective (Khalabat, 2011). The National Bank of Pakistan was established in 1949(Qayyum\& Anwar, 2011). Agriculture Development Bank and Industrial Development Bank of Pakistan were the most outstanding establishments during the period of 60's and 70's (Ghazanfar, 2011). In 1961 , both these financial institutions were established. The number of banks grew in Pakistan and reached to 14 with 3323 offices were established in Pakistan and 74 offices were in foreign countries (Shirazi, 2010).

\subsection{Phases of Banking in Pakistan}

\subsubsection{Nationalization of Banks}

The banking industry of Pakistan progressed rapidly after 1974(Shirazi, 2010). In 1974, the nationalization policy was announced by the government which was aimed at promoting welfare by distributing credit to all classes of the society and develops the economy of Pakistan by using the capital which was in the hands of few bankers (Ghazanfar, 2011). This policy was designed because of the Bank Nationalization Act (Shirazi, 2010). According to this act, six banks were established by merging thirteen commercial banks (e.gHabib Bank Limited, Standard Bank Limited, Commerce Bank Limited, Muslim Commercial Bank Limited, United Bank Limited, Allied Bank Limited, Australia Bank Limited, Bank of Bahawalpur Limited, Premium Bank Limited, Pak Bank Limited, Sarhad Bank Limited, Punjab Provincial Cooperative Bank Limited and Lahore Commercial Limited). The six banks were National Bank of Pakistan, United Bank Limited, Habib Bank Limited, Muslim Commercial Bank Limited and Allied Bank Limited (Khalabat, 2011). The Pakistan Banking Council was established in 1974 which coordinated the functions of nationalized commercial banks (Shirazi, 2010). The nationalization of banks is divided into three phases (Ghazanfar, 2011). Bank Bhahawalpur was merged with National Bank of Pakistan in the first phase. Premier Bank Limited was consolidated with Muslim Commercial Bank. Sarhad Bank Limited and Pak Bank Limited were combined with Allied Bank. In second phase, Commerce Bank Limited was combined with United Bank Limited. In third phase, Standard Bank Limited was fused with Habib Bank Limited. 


\subsubsection{Post Nationalization Period}

The banking sector of Pakistan continued to grow but it was mainly benefitting the politicians and the government (Khalabat, 2011). Political influence affected the period of 1980 to 1990 in which the hiring of board of directors and chief operating officers was not done on merit (Qayyum, 2007). Corruption was at its peak in this era, as loans were taken which were not contributing towards the growth of the banking industry (Khalabat, 2011). In 1981, Islamic banking was introduced which focused on interest free banking. Interest free loans were introduced and were given to farmers, students and fishermen (Khan, 2008). Financial schemes were introduced which Hire and Purchase were Financing, Musharika Financing and Modaraba Financing (Shahid et al., 2010).

\subsubsection{Privatization of Banks}

Nationalization Act 1991 was modified to benefit the banking sector of Pakistan (Bonnaccorsi\& Hardy, 2005). A total of 23 banks were founded (Kemal, 2000). Domestic licenses were issued to 10 banks (Khalabat, 2011). Muslim Commercial bank was denationalized (Khalid, 2006). In 1993, the ownership of Allied bank was transferred to its employees (Khalabat, 2011). In 1997, four banks were still operating under the control of the government. These banks were facing challenges from 27 foreign banks and 21 domestic banks (Khalid, 2006). The privatization played a positive role by managing the interest rates and abolished the credit ceilings (Khalabat, 2011). Due to these changes the government loan rates were set according to market rates and the government securities were auctioned (Khalid, 2006).

\subsubsection{Post Privatization}

After privatization, the regularity powers were restored because of modifications in Banking Companies Ordinance 1962 and Bank of Pakistan Act 1956(Ghazanfar, 2011). This resulted in improved internal controls, banks supervision and corporate governance (Khalabat, 2011, para 7). Small and Medium Enterprise (SME) finance, consumer and mortgage finance was encouraged. Due to liberalized policies of banking, the financial sector improved.

\section{Current State Of Banking Sector Of Pakistan}

Pakistan's banking industry has proved to be playing a supportive role in growth and development of the economy of Pakistan. According to the State Bank of Pakistan Act, the system of banking is running under a two-tier pattern concept in which it includes commercial banks, specialized banks, state owned banks, microfinance banks, development finance institutions and Islamic banks. By end June 2010, the number of commercial banks in Pakistan's banking industry increased to 36. Out of which 25 were private banks, seven were foreign banks and four were public banks. Besides these banks, four specialized banks were also operating with 9,087 braches in different cities. In addition, six Islamic banks were also operating.

In the same year, Industrial \& Commercial Bank and Sindh Bank were issued licenses. Opportunities were created by the former bank in the field of trade and finance with the help of Chinese companies which were working in Pakistan. The latter bank created opportunities in the field of agriculture. According to the statistics of State Bank of Pakistan (2013), the banking industry is comprised of multicultural nature of banks and financial institutions. There are 39 commercial banks, 11 microfinance banks, 7 Islamic banks, 5 nationalized scheduled banks, 4 specialized banks, one central bank and 1 housing finance company.

\section{Rational Behind Growth In The Banking Sector OF Pakistan 5.1 Economic Development and Performance of the Banking Sector of Pakistan}

To make the banking sector more resilient and competitive, some structural changes were made by the State Bank of Pakistan. As the banking sector of Pakistan played an important role in the growth and economic development of Pakistan, certain questions were raised which asked for the justification of the reforms in the banking sector.

i. Why banking sector of Pakistan need healthy performing banks.

ii. How the State Bank of Pakistan help in improving the performance of banks.

iii. How the State Bank of Pakistan policies are supported by the government.

iv. How the reforms in the banking sector help the depositors, businessmen and the common man.

The growth in the banking sector is directly linked with the economic growth and development of the country. So, reforms introduced in 1990 played an important role in generating revenue for the banking sector. The reforms were needed because banking sector is the only sector which survives the economic shocks.

\subsection{Removal of Restriction on Consumer Finance}

The restrictions which were imposed by the State Bank of Pakistan were removed and banks were given more liberty to offer a variety of consumer finance products. 


\subsection{Micro financing}

The State Bank of Pakistan brought microfinance under its regulation and supervision so the facility of rural finance and micro credit could be provided to a large population of Pakistan. The regulatory and licensing requirements were made easy. The micro credit institutions were opened at provincial and national level.

\subsection{Establishment of Small and Medium Enterprise Banks}

Small and Medium Enterprise(SME) Banks were established by the State Bank of Pakistan to empower the entrepreneurs of the country by providing credit on easy terms. The loans were approved on the basis of asset conversion cycles and cash flow generation without any collateral. The SME establishment played a major role in the growth of the banking sector of Pakistan.

\subsection{Reduction of Corporate Tax}

The Government of Pakistan played an important role in the growth of the banking sector by reducing the corporate tax from $58 \%$ to $35 \%$. This encouraged the banking sector to become more profitable.

\subsection{Introduction of Islamic Banking}

Islamic banking was introduced in Pakistan because it supports the idea of interest free banking which is a very popular idea. Since Pakistan is an Islamic State and most of the population of Pakistan avoids using the conventional banking because it is based on interest.

\subsection{Privatization of Banks}

The privatization of banks by the government of Pakistan resulted in growth in the banking sector because of increased competition. The assets which were previously in the hand of the public sector were transferred to the private sector. After 1990, 80 percent of the assets were transferred to the private sector.

\subsection{Mortgage Financing}

The banks of Pakistan started to provide a wide variety of banking services in mortgage financing and some steps were taken to encourage the mortgage financing in Pakistan. The upper ceiling was raised; the tax was reduced on the interest payment of the mortgage. The long term funds were raised through rated and listed instruments so the long term assets and liabilities could be matched with them.

\subsection{Introduction of Agriculture Credit Schemes}

The commercial banks of Pakistan played an important role in lending credit to the agriculture sector through different schemes. The previous schemes were limited to only production loans but after the liberalization of the banking sector, the whole agriculture sector was provided loans through different schemes.

\section{Growth In THE BANKING SECtor OF PAKISTAN AND THE IMPACT ON REVENUE GENERATION 2007 TO 2012}

The banking sector of Pakistan relies mostly on the government policies of Pakistan. After the 2002 elections, the newly established government formulated policies which supported the growth of the banking sector. This sector in the past was in the hands of the public sector but after the new policies, competition was seen. The banking sector turned profitable after 2002. The banking sector generated revenue of $\$ 1.1$ billion in 2006. The world saw the Global Financial Crisis which was difficult on all sectors of the economy. Despite all the difficulties, the banking sector of Pakistan showed stiffness and it was able to handle the pressures of the Global Financial Crisis. During the crisis, the large banks maintained a very healthy position and the smaller banks started to offer their services to niche markets so they could survive the crisis.

Table 1. Financial Soundness Indicators

\begin{tabular}{|c|c|c|c|c|c|c|c|c|c|}
\hline & & & & & & & & & Percent \\
\hline & 2007 & 2008 & 2009 & $\begin{array}{c}\text { December } \\
2010\end{array}$ & $\begin{array}{c}\text { March } \\
2011\end{array}$ & $\begin{array}{l}\text { June } \\
2011\end{array}$ & $\begin{array}{c}\text { September } \\
2011\end{array}$ & $\begin{array}{c}\text { December } \\
2011\end{array}$ & $\begin{array}{l}\text { March } \\
2012\end{array}$ \\
\hline Growth Rates & YoY & YoY & YoY & YoY & YoY & YoY & YoY & YoY & YoY \\
\hline Assets & 18.8 & 8.8 & 15.8 & 9.3 & 11.7 & 13.7 & 17.2 & 15.0 & 16.6 \\
\hline Loans(Net) & 10.7 & 18.3 & 2.1 & 3.1 & 5.2 & 4.7 & 3.0 & $(0.2)$ & 2.8 \\
\hline Deposits & 18.4 & 9.4 & 13.5 & 13.9 & 13.5 & 16.3 & 14.9 & 14.5 & 16.5 \\
\hline Investments(Net) & 53.1 & (15.4) & 59.9 & 22.2 & 27.9 & 38.4 & 51.9 & 42.5 & 39.5 \\
\hline Equity & 35.3 & 3.4 & 17.3 & 5.9 & 5.6 & 8.1 & 14.9 & 12.4 & 12.9 \\
\hline
\end{tabular}

Source: State Bank of Pakistan

\subsection{Assets}


The financial soundness indicators provided by the State Bank of Pakistan show how the banking sector survived through the Global Financial Crisis from 2007 to 2012. The assets of the banking sector which were 18.8 percent in 2007 reduced to 8.8 percent in 2008. But as the banking sector slowly recovered from the crisis, the assets started to grow and then again they regained their position in March 2012 which was 16.6 percent.

\subsection{Loans (Net)}

The loans (net) which were 10.7 percent in 2007 showed growth to 18.3 percent in 2008. This growth is because the government borrowed money from the banking sector to fund its economic budget. After 2009, the banking sector has not performed well in lending loans because of high interest rates till March 2012.

\subsection{Deposits}

The deposits which were 18.4 percent in 2007 reduced to only 9.4 percent in 2008 but with the passage of time, the deposits of the banking sector grew and reached 16.5 percent in March 2012.

\subsection{Investments (Net)}

The investments (net) were 53.1 percent in 2007 which got negative in 2008 because of the Global Financial Crisis as every investor wanted to save their investment. After the Global Financial Crisis, the investments (net) grew to 39.5 percent in March 2012.

\subsection{Equity}

The banking sector equity was 35.5 percent in 2007 which was reduced to only 3.4 percent in 2008 but with time, the equity was regained by the banking sector to 12.9 percent in March 2012.

\section{CONCLUSION}

This research paper concludes that the banking sector is still resilient after the Global Financial Crisis. It not only survived the shock but also regained its position. After analyzing the financial soundness indicators, growth is indicated. The banking sector of Pakistan can support and revive the economy of Pakistan. The performance of this sector is outstanding and thus it can be used towards the growth and development of the economy. The banking sector has shown a lot of potential and it can generate a lot of revenue for the country. Privatization of the banking sector is the main reason behind its growth and thus the liberalization of the sector further helped in the growth of the banking sector of Pakistan.

\section{RECOMMENDATIONS}

The banking sector of Pakistan stayed profitable even after the Global Financial Crisis, so it is recommended that the government of Pakistan must ensure macroeconomic stability so this sector can continue to perform well. The banking sector must also focus over the capital adequacy and productivity so they can have a positive Return on Assets(ROA).Moreover, the State Bank of Pakistan must support the private banking sector to engage in competition so they can improve their services.

\section{REFERENCES}

[1] Hardy, C.D., \& Emilia Bonaccorsi Di Patti (2001). Bank Reform and Bank Efficiency in Pakistan.IMF Working Paper, 01/138: Washington DC.

[2] Akhtar, Muhammad, Ali, Khizer.,\&Sadaqat, Shama (2010). Performance Efficiency of Commercial Banks of Pakistan: NonParametric Technique Data Envelopment Analysis (DEA). Asian Journal of Business and Management Sciences, 1(2), 150-156.

[3] Khalabat, Amna (2011). History of banking in Pakistan- of humble origins and vast potential. The Express Tribune, retrieved from http://tribune.com.pk/story/286458/history-of-banking-in-pakistan--of-humble-origins-and-vast-potential/

[4] State Bank of Pakistan. (2012). Banking Statistics of Pakistan 2011-12.State Bank of Pakistan, Karachi.

[5] Ghazanfar, Mohammad (2011). Internship Report on National Bank of Pakistan.

[6] Qayyum, Abdul (2007). Financial Sector Reforms and the Efficiency of Banking in Pakistan.South Asian Network of Economic research Institutes.

[7] Shirazi, Ahmed (2010). Internship Report on MCB Bank Limited.

[8] Qayyum, Abdul\&Anwar, Saba (2011). Impact of monetary policy on the volatility of stock market in Pakistan.International Journal of Business and Social Science, 2, (11), 18-24.

[9] Shahid, Haseeb.,Rehman, Ramiz., Niazi, Ghulam., \&Raoof, Awais (2010). Efficiencies Comparison of Islamic and Conventional Banks of Pakistan.International Research Journal of Finance \& Economics, 49, 25-44.

[10] Bonaccorsi Di Patti, E., \& Hardy, D. C. (2005). Financial Sector Liberalization, Bank Privatization, and Efficiency: Evidence from Pakistan. Journal of Banking \& Finance, 29 (8-9), 2381-2406.

[11] Kemal, A. R. (2000) Privatization in Pakistan. Privatization in South Asia:Minimizing Negative Social Effects through Restructuring. New Delhi: ILO, 143-74.

[12] Khalid, Umer (2006). The effect of privatization and liberalization on banking sector performance in Pakistan.SBP Research Bulletin, $2(2), 401-425$. 